\title{
LT COL STANISŁAW MICHOWSKI AND CONSPIRACY IN THE ARMY. A SANCTIONED CRIME
}

\author{
Marcin Arbuz \\ Muzeum Sił Powietrznych w Dęblinie \\ Air Force Museum in Dęblin \\ e-mail: arbuzmarcin01@gmail.com
}

\begin{abstract}
The article presents Lt Col Stanisław Michowski in the context of political persecutions taking place at the turn of the 1940s and the 1950s in the postwar Poland. Michowski was an airman of the Polish Armed Forces, who after the Second World War returned to homeland. He recommenced his service in the army, but he was expelled and arrested shortly afterwards. He was one of the defendants, and was later convicted and executed, during what historiography of the period calls "the conspiracy in the army". The operation was carried out by the Main Directorate of Information of the Polish Army and was aimed against prewar soldiers, soldiers of the Polish Armed Forces in the West, or those who were active in resistance in Poland during the Second World War. As an airman, Michowski was accused of participating in the so-called conspiratorial group of the Air Forces. The alleged aim of the group was conspiring against the communist government and their forceful abolishment with the help of the army. The overwhelming majority of accusations were ungrounded. Confessions fabricated during many hours of interrogations served as a basis for bills of indictment resulting in numerous executions. One of the executed was Lt Col Stanisław Michowski.
\end{abstract}

Keywords: splinter trial, Stanisław Michowski, conspiracy in the army, political persecutions in Poland after 1945.

The conclusion of the Second World War in Europe, after almost six years of combat, brought long-awaited peace. On 1 May 1945 the Polish Armed Forces in the West consisted of ca. 194,500 soldiers ${ }^{1}$. The Polish Armed Forces consisted of over 14,000 airmen ${ }^{2}$. The forces took part in the most important, sea, and land battles, and significantly contributed to the victory over Nazi Germany. For Poles, however, the conclusion of the Second World War did not bring the

1 K.A. Tochman, Z ziemi obcej do Polski. Losy żotnierzy PSZ na Zachodzie, którzy powrócili do kraju po II wojnie światowej, t. 1, Zwierzyniec 2006, p. 211.

2 W. Matusiak, Powojenne losy elity polskiego lotnictwa, „Biuletyn Instytutu Pamięci Narodowej”, 3(2011), p. 86. 
expected outcome, i.e. freedom and return to the state of affair before 1939. Due to aggressive Soviet politics and political agreements of the Big Three, Poland was subjugated to the Union of Soviet Socialist Republics. Despite creating the appearances of democracy, communists were the actual rulers. The Provisional Government of National Unity in Warsaw was recognized by British and American authorities and the Polish government in London ceased to be recognized, which created a difficult political situation ${ }^{3}$. As a consequence, the plans of repatriating the Polish army in its entirety whole was uncertain. The government in Poland had its own plan for repatriating soldiers stationing abroad. Officially, the attitude of communist authorities towards soldiers outside Poland was positive, but in fact everyone returning from the West was treated at least with suspicion and more often as an alleged spy. Nonetheless, shortages of soldiers forced the communists to use the Polish Armed Forces soldiers. In 1945, an overwhelming majority of air force personnel in Poland were Soviets with only 10 percent were Polish officers ${ }^{4}$. Communist authorities assumed that by 1947 they would have changed this state of affairs, i.e. the air force personnel would consist entirely of Polish citizens. Obviously, the airmen fighting in Western Europe during the Second World War were very useful in this respect. They were well trained and had enormous experience in combat, so they could be excellent commanders and instructors for new generations of pilots. Indeed, some of the airmen returning from the West reentered the army. Due to this (and other factors), in 1946 Soviet citizens were one third of the personnel and one year later the number decreased to 10 percent $^{5}$. However, the contemporary political circumstances did not allow the returners to feel confident about their place in the army. In the second half of the 1940s, a wave of trials and politically motivated investigations swept through the communist-dominated Republic of Poland, resulting in numerous death sentences. The defendants were mainly the soldiers of pro-independence resistance during the Second World War - those who after the war continued guerrilla warfare against the communist enemy, but also those who left the conspiracy and tried to start a normal life in the new reality. Persecutions swept through the army as well.

As a result of political decisions announced in 1949 at the 3rd Congress of the Central Committee of the Polish United Workers' Party, actions were taken to elim-

\footnotetext{
3 J.A. Radomski, Demobilizacja Polskich Sit Zbrojnych na Zachodzie w latach 1945-1951, Kraków 2009, p. 25.

4 W. Matusiak, Powojenne losy..., p. 87.

5 Ibidem, p. 87.
} 
inate broadly understood alien ${ }^{6}$ or "hostile element" from the Polish Army. Thus, from the late 1949 to 1954, 1276 officers were expelled from all kinds of armed forces for political reasons ${ }^{8}$. In the period under discussion, soldiers were accused mainly of espionage-related crimes and participation in illegal organizations. In 1947-1949 two cases of this sort were most famous. In the so-called Bydgoszcz case, reservists were accused of participating in an illegal organization called The Knights of the Queen of Poland, allegedly aiming at abolishing of the government. The other one was the so-called Zamość-Lublin case. In both cases the sentences were very harsh. Apart from the sentences, however, the most dramatic were the methods of the investigators. Prisoners were regularly beaten, usually very brutally, usually resulting in permanent mutilations and sometimes deaths ${ }^{9}$. The methods used by the Main Directorate of Information of the Polish Army (MDI) from 1945 were formally ended when the Head of 4th department (investigative) of the MDI, Lt Col Aleksander Malkowski, was replaced by Col Władysław Kochan, who assumed the post in July $1948^{10}$. The new head changed the methods of interrogation or rather emphasized other aspects. Physical tortures, i.e. beating and maltreating prisoners, were officially prohibited and other means of gathering information were used instead. The main method was the so-called konwejer, i.e. long (up to 20 hours) interrogation of one suspect by several interrogators, with short breaks. Additional methods were used, e.g. enforcing immobile posture, standing very close towards a wall, confinement in a dark cell filled with water, etc. Intimidation, blackmailing, and vulgar language were also common. This sort of interrogation could last up to several months. Effectively, everyone submitted to the MDI could admit to the actions they had never performed ${ }^{11}$. What is more, from the perspective of the MDI, even the very fact of being arrested confirmed that the detainee was guilty. This was the backdrop for what is commonly known as the conspiracy in the army.

The general guidelines of the action were sketched during the 3rd Congress of the Central Committee of the Polish United Workers' Party in November 1949

\footnotetext{
6 Alien element - "sons of lower state or local clerks, intelligentsia, craftsmen employing up to three contracted workers, farmers owning from 11 to 15 ha of land, reservist officers from before the Second World War - regardless of their class origin". J. PoKsiŃSKI, "TUN". Tatar-Utnik-Nowicki. Represje wobec oficerów wojska polskiego w latach 1949-1956, Warszawa 1992, p. 7.

7 Hostile element - "sons of merchants ans entrepreneurs, higher state officials of interwar Poland, functionaries of prewar Ministry of Domestic Affairs and officers of the Polish Army, freelance professionals, farmers owning more than 15 ha of land, landlords". Ibidem, p. 7.

8 Z. PALski, Informacja Wojska Polskiego 1943-1957, Warszawa 2016, p. 146.

9 Ibidem, p. 123.

${ }^{10}$ Ibidem, p. 126.

${ }^{11}$ Ibidem, p. 127-128.
} 
and it was to eliminate undesired persons from the army ${ }^{12}$. A theory of a great conspiracy, embracing land, naval, and air forces, was fabricated. The conspirators allegedly intended to seize power in military institutions and forcefully abolish the government. The purge was paralleled by the fight against the so-called rightist-nationalist deviation in the Party itself ${ }^{13}$. Apart from the premonitions of several earlier events, the purge started with the investigation related to Gen Stanisław Tatar, Col Marian Utnik, and Col Stanisław Nowicki, and officers allegedly collaborating with them, including generals (Div. Gen. Stefan Mossor, Div. Gen. Jerzy Kirchmayer, Brig. Gen. Józef Kuropieska, Brig. Gen. Wacław Komar, and others). The case known in historiography as "TUN" was "the tip of the iceberg", accompanied by the so-called splinter cases, as a result of which most death sentences were issued. Particularly tragic were the consequences of two trials in the case of the so-called group of conspiracy in the Air Forces, concluded with twelve death sentences, eight of which were carried out. One of the alleged conspirators was Lt Col Stanisław Michowski.

Stanisław Michowski was born on 5 November 1900 in Innokientievskaya train station near Irkutsk in Siberia ${ }^{14}$. He was a son of Józef Michowski and Kazimiera Michowska née Bartold vel Bartoldi ${ }^{15}$. In his youth Stanisław Michowski's father was engaged in "activity against the tsarate" 16 ; particulars of the activity are unknown, but as a result he was sent to Siberia in 1881, where he later brought his family. As a construction technician, he took part in the construction of Siberian railway and from 1906 he worked for the East-Chinese railway as a clerk ${ }^{17}$. Józef's son, Stanisław Michowski, spend his youth in a foreign land. Born in late 1900,

\footnotetext{
12 J. PoKsiŃski, “TUN”..., p. 90-91.

13 "Rightist-nationalist deviation" should be understood in terms of the conflict inside the Polish Workers' Party initiated officially during the session of the Central Committee of the Polish United Workers' Party at the turn of August and September 1948, when Władysław Gomułka and his allies were accused by the party's authorities headed by Bolesław Bierut of deviating from the correct policy of the party, propagating the so-called Polish way towards socialism and the independentist tradition of the Polish Socialist Party. Gomułka was also accused of installing hostile agents inside the party, etc. As a consequence, from 2 August 1951 to 13 December 1954 Władysław Gomułka was under custody. J. EISLER, Siedmiu wspaniatych. Poczet pierwszych sekretarzy KC PZPR, Warszawa 2014, p. 190-200.

${ }^{14}$ Archiwum Instytutu Pamięci Narodowej [AIPN], 1840/22, Soldier's personal file: Lt Col Michowski Stanisław, f. 25.

${ }^{15}$ Marek Michowski. Syn bohatera Dywizjonu 305 [memories of Marek Michowski, son of Stanisław Michowski], "Polskie Radio" [online], 21 X 2016 [accessed: 26 I 2019], available at: $<$ https://www. polskieradio.pl/8/755/Artykul/1681062,Marek-Michowski-Syn-bohatera-Dywizjonu-305>.

${ }^{16}$ AIPN, 1840/22, Soldier's personal file: Lt Col Michowski Stanisław, f. 6.

${ }^{17}$ Ibidem, f. 25.
} 
he began his education at the age of 7 in the Polish Popular School in Harbin ${ }^{18}$ in the Chinese Manchuria ${ }^{19}$. After 3 years, in 1910, Michowski began education in the Private Russian Gymnasium "Ravast", and from 1914 he continued education in the Private Russian Gymnasium "Anders"20. In the 5th year of his gymnasium education, Michowski started giving private classes, in order to support (along with his older siblings) his mother, which was very important taking into consideration his father's death in $1912^{21}$. According to Marek Michowski's (Stanisław's son) memories, his father worked during summer as a seaman on transport vessels ${ }^{22}$, even though Stanisław Michowski never mentioned this in questionnaires ${ }^{23}$. Michowski's education at this stage finished in 1919 with a secondary school examination ${ }^{24}$. He then moved with his mother to Vladivostok and in 1920 he moved to Shanghai, were he lived until June 1922 working, as he himself called it, in "one of the British companies" 25 . Michowski then decided to go to Poland and he departed in August 1922. Soon after reaching Warsaw in October 1922, he enrolled to the Law and Political Studies Department of the University of Warsaw ${ }^{26}$. He left after finishing two years of university education and began his military career. At first, he studied in the Cadet School in Warsaw becoming a squad and platoon commander in the 65th Infantry Regiment. His love for aviation made him join the Air Force Officer School in Grudziądz in August 1925, graduating on 15 August 1927 as an observer in Dęblin, where the school was relocated. Michowski's first assignment was Poznań and the 3rd Air Force Regiment. He flew there as an observer in the 35th and then 32nd Air Firce Squadron ${ }^{27}$. On 15 February 1928 he was promoted in the air force corps to Second Lieutenant (with the 25th rank) by the President of the Republic of Poland Ignacy Mościcki ${ }^{28}$. In October 1929 he was assigned to a course in

${ }^{18}$ Harbin, "Britannica" [online, accessed: 20 II 2019], available at: < https://www.britannica.com/ place/Harbin>; Harbin, "Encyklopedia PWN" [online, accessed: 20 II 2019], available at: <https:// encyklopedia.pwn.pl/haslo/Harbin;3910038.html>.

${ }^{19}$ AIPN, 1840/22, Soldier's personal file: Lt Col Michowski Stanisław, f. 5.

${ }^{20}$ Ibidem.

${ }^{21}$ Ibidem, f. 6.

${ }^{22}$ Marek Michowski. Syn bohatera...

${ }^{23}$ AIPN, 2386/13466, Court files Volume IV. Memorandum and additional materials. Life story written on 18 May 1948 , f. 46.

${ }^{24}$ AIPN, 1840/22, Soldier's personal file: Lt Col Michowski Stanisław, f. 5.

${ }^{25}$ AIPN, 2386/13466, Court files Volume IV. Memorandum and additional materials. Life story written on 18 May 1948, f. 46.

${ }^{26}$ Ibidem.

${ }_{27}$ In late 1928, the name Air Force Squadron was changed to Line Squadron. J. Pawlak, Polskie eskadry w latach 1918-1939, Warszawa 1989, p. 233.

${ }^{28}$ Zarzadzenia Prezydenta Rzeczypospolitej ['Ordinance of the President of the Republic of Poland'], "Dziennik Personalny" ['Personal Journal'], 21 III 1928, p. 2, available at: <http://www.wbc. 
Communication Officer School in Zegrze, which he finished in March 1930. He was also promoted to lieutenant and returned to the 3rd Regiment as a commander of the school's communication platoon in the school's squadron; at the same time he was a tactical officer of the 32nd Squadron. From October 1932 he was an adjutant in the 3rd Regiment. During his stay in Poznań, he met Irena Tomaszewska, who he married on 24 January 1933. They had two children: Marek Stanisław and Danuta Irena. In October 1933 Michowski was relocated to the Center of Air Force Officer Training as a platoon commander and a commander of a cadet squadron. He performed this function until August 1934. He then became the manager of the shooting and bombarding department of the air force school in Dęblin, holding the post until June 1938. Earlier, in January 1936, he was promoted to captain. In June 1938 Michowski became a student of the Higher Air Force School of the Higher Military School in Warsaw. After graduating in June 1939, the airman was assigned to the 1st Air Force Regiment in Warsaw as a tactical officer of bombarding grouping. He held this post until 25 August, when he became an information officer in the staff of the Bombarding Brigade, where he served when the Second World War began ${ }^{29}$. Stanisław Michowski evacuated from Warsaw with the brigade's staff in the night of 9/10 September 1939. He crossed the Polish-Romanian border on 20 September and headed with the staff to Bucharest, where he was interned ${ }^{30}$. He remained in the internment camp for over a month, escaped on 2 November, and evacuated by embarking on a ship in the port Balchik.

He traveled by sea; he stopped in Turkey, then he went to Malta, and reached France on 13 November $1939^{31}$. There, he reached a base of Polish airmen near Lyon, where he stayed until March 1940 and then went to the base Clermont-Ferrand, where he was a commander of 30 observer and shooter cadets who trained there $^{32}$. After the defeat of France, he evacuated to Great Britain on 20 June 1940 and arrived there on 27 June. In Great Britain, he initially came to a rally point in Innsworth Lane and then to Blackpool. He waited for an assignment performing the function of training squadron commander in a radiotelegraph operator school. Later he was assigned to the school in the Royal Air Force (RAF) station Dumfries and after finishing a training in May 1942 he was assigned to the training center

poznan.pl/dlibra/applet?mimetype $=$ image $\% 2 \mathrm{Fx}$. djvu\&sec $=$ false $\&$ handler $=$ djvu_html5\&content_url=\%2FContent $\% 2$ F69628\%2Fdirectory.djvu $>$ [accessed: 16 II 2019].

${ }^{29}$ AIPN, 1840/22, Soldier's personal file: Lt Col Michowski Stanisław, f. 8.

${ }^{30}$ Ibidem.

${ }^{31}$ AIPN, 2386/13466, Court files Volume IV. Memorandum and additional materials. Life story written on 18 May 1948, f. 46.

${ }^{32}$ B. Belcarz, Polacy w Clermont-Ferrand, "Lotniczy Magazyn Historyczny 'Gapa”, 14(2015), p. 36. 
for bombarding air forces in the RAF station Bramcote, where he studied until August that year. Eventually, he received a combat assignment to the 305th Bombardier Squadron of Ziemia Wielkopolska of Marshal Józef Piłsudski. During his service from August 1942 to March 1943 Michowski flew 26 combat missions. For his achievements, he receive the War Order of Virtuti Militari (V class) and the Cross of Valor (three times) ${ }^{33}$. From March 1943 Michowski taught for a year in the Higher Military School of Air Force in Peebles in Great Britain ${ }^{34}$. He was also promoted to major in September $1943^{35}$. As a consequence of his achievements, Michowski was sent to the USA in March 1944. There he stayed until October 1944 in the United States Army Command and General Staff School, initially as a student and an intern, then as a lecturer. After that he returned to Great Britain and started teaching in the Higher School of Air Force in Weston Super Mare, where he worked until May $1946^{36}$. He received the title and the prerogatives of a certificated officer ${ }^{37}$. The end of the war faced Maj Stanisław Michowski, like many of his colleagues, with a serious dilemma concerning the future. He could go to Australia, as insisted his sister who lived there, but first he wanted to find his relatives. Michowski's family lived in Warsaw during the early days of the Warsaw Uprising and were taken to the German Nazi concentration camp in Auschwitz ${ }^{38}$. Stanisław Michowski was aware of their fate, so in order to find his family in the second half of 1945 he was visiting interim camps. He did not find his family, but in October 1945 he received a letter from Poland. It turned out that his relatives were safe and sound. Initially, Michowski was not inclined to return to homeland; he consulted this matter with his wife proposing to emigrate to Australia. Irena Michowska decided to stay in Poland waiting for her husband's return ${ }^{39}$. Similarly to many other airmen, the decision about return was influenced by family matters. The wife and the children caused Michowski to prepare to his return. Eventually, on 6 May 1947 he set off on the vessel Victoria Staar from Edinburgh and reached Gdańsk on $9 \mathrm{May}^{40}$. One day after arriving to Poland, Michowski, according to the guidelines from the Polish attache in London,

${ }_{33}$ AIPN, 2386/13466, Court files Volume IV. Memorandum and additional materials. Life story written on 18 May 1948, f. 47.

${ }^{34}$ J. PoKsińsKi, Victis Honos, Warszawa 1994, p. 53.

${ }^{35}$ AIPN, 1840/22, Soldier's personal file: Lt Col Michowski Stanisław, f. 8.

${ }^{36}$ Ibidem.

37 J. PoKsiŃsKi, Victis..., p. 53.

${ }^{38}$ Marek Michowski. Syn bohatera...

${ }^{39}$ AIPN, 00161/357, Court files of the case of Lt Col Michowski Stanisław. Report of interrogation of Stanisław Michowski from 29 XI 1951, f. 24-25.

${ }^{40}$ Centralne Archiwum Wojskowe [CAW], II.53.35965, Register of soldiers returning to Poland for permanent residence from foreign military units, item 1270 . 
Col Maksymilian Chojecki, went to Warsaw and reported to Gen. Wacław Komar. He informed about his intention to return to the army and the general assured him about his help. After several days of leave spent with family, on 20 May 1947 Michowski, in accordance with the arrangements made with Gen. Komar, began service in the 2 nd Department of the General Staff ${ }^{41}$. At first, he translated foreign documentation ${ }^{42}$ and later studied rocket and jet propulsion used in foreign constructions while working in the Research Bureau of Air Force Section ${ }^{43}$. In February 1948 he joined the Polish Workers' Party and then, after its transformation, he became a member of the Polish United Workers' Party (membership card No. 0668471$)^{44}$. His joining the party should be viewed as a pragmatic step and a condition for his further employment in the army rather than manifestation of his political views. Michowski's value in the new workplace was appreciated, which was reflected in positive professional evaluations and a promotion to lieutenant colonel on 22 July 1948. The promotion was motivated by extraordinary achievements and impeccable military service ${ }^{45}$.

With time, however, good performance and competence had to collide with ideology embracing ever larger domains of life. A harbinger of upcoming events was Michowski's evaluations by the deputy head of the 2nd Department of the General Staff, Col Witold Leder. The evaluation was generally extremely positive and appreciated the expertise of the officer, but included a note that was the most important at that time: "Due to the service in Sanation Army and the air force under English command, he cannot work in the 2nd Department"46. It turned out that the airman could not work not only in the 2nd Department, but also anywhere else in the Polish army. After leaving the military, he attempted to find employment in the central office of book distribution Dom Książki, but eventually was employed in the Company of Mechanization and Construction Equipment in Warsaw from 9 May 1950. This did not last long. On 27 November $1951^{47}$ around 2 PM an MDI officer Cpt Onopczuk came to the company. He found Michowski and under the pretext of having a private conversation he took the officer outside, where a car with the rest of the officers awaited. They went to the seat of the MDI at Chałubińskiego Street.

${ }^{41}$ AIPN, 1840/22, Soldier's personal file: Lt Col Michowski Stanisław, f. 46.

${ }^{42}$ AIPN, 2386/13418, Court files of the case of Adamecki and others. Stenogram of the trial, testimony of Michowski Stanisław, f. 17.

${ }^{43}$ J. PoKsińsKi, Victis..., p. 54.

${ }^{44}$ AIPN, 0423/5637, The case concerning Stanisław Michowski, f. 51.

${ }^{45}$ AIPN, 1840/22, Soldier's personal file: Lt Col Michowski Stanisław, f. 40.

${ }^{46}$ AIPN, 0423/5637, Case concerning Stanisław Michałowski, f. 72.

${ }^{47}$ AIPN, 00161/357, Court files of the case of Lt Col Michowski Stanisław. Application for arrest, f. 9. 
There, Michowski was transferred to the chief of detention Cpt Peszel, who carried out a body search ${ }^{48}$. According to the archives, no items suggesting hostile activity were found. The group of officers who brought Michowski to the arrest also planned to carry out a search in his apartment at Grottgera Street. They went there at 17.00, but no one was home. At 6.00 AM the following day they returned under the command of Lt Wacław Kryński and entered the apartment, where they met Michowski's wife, children, and his cousin Tatiana Michowska with her son ${ }^{49}$. During the search, Kryński wrote down 19 items. Archives provide no detailed description of the items; only a general list is available ${ }^{50}$. According to the Kryński's note "no discrediting items were found [...]" as well, but no suspicious items were found either. The search ended at $13.30^{52}$. On the same day, an MDI officer Cpt Zdzisław Michałowski decided about commencing an investigation against the airman ${ }^{53}$ and requested detention ${ }^{54}$. A deputy military attorney Gen. Col Antoni Lachowicz read the request and decided about temporary detention until 28 February 1952 concluding that "there is a serious threat that the defendant will attempt to tamper the witnesses and destroy evidence of crime" ${ }^{55}$. The first interrogation took place on 29 November $1951^{56}$. Michowski told his life story multiple times, which was a standard procedure in the MDI. The interrogators hoped that new details would appear with a new iteration and encouraged the prisoner to disclose new details of his life. Obviously, they expected information about conspiracy and espionage. With time, the prisoner was so confused by constant repetitions that it was much easier to add fictional details. The interrogators knew when to suggest to the prisoner an alternative account of events, which he, broken and exhausted, confirmed and extended. In order to bring the prisoner to that state, apart from many hours and many days of questioning, the

48 AIPN, 2386/13466, Court files of the case of Lt Col Michowski Stanisław. Note to the Head of the 4th Department of MDI Ministry of National Defense concerning the apprehension of the suspect Stanisław Michowski, written by Lt Kryński, the Head of the 1st Section of the 5th Department of MDI Ministry of National Defense, f. 52.

${ }^{49}$ Ibidem.

${ }^{50}$ AIPN, 00161/357, Court files of the case of Lt Col Michowski Stanisław. Report from apartment search, f. 13.

${ }^{51}$ Ibidem, f. 52.

${ }^{52}$ Ibidem.

${ }^{53}$ AIPN, 00161/357, Court files of the case of Lt Col Michowski Stanisław. Decision on commencing an investigation, f. 8 .

${ }^{54}$ Ibidem, Court files of the case of Lt Col Michowski Stanisław. Application (for arrest), f. 9.

${ }^{55}$ Ibidem, Court files of the case of Lt Col Michowski Stanisław. Decision about preliminary custody, f. 10 .

${ }^{56}$ Ibidem, Court files of the case of Lt Col Michowski Stanisław. Prisoner questionnaire, Description, f. $15-17$. 
interrogators informed Michowski that, for example, other prisoners had already confessed and, what is more, they named him as a part of enemy conspiracy.

After many days of long interrogations with very short breaks for rest, severely sleep-deprived prisoners were eventually broken, often as a result of fits of mania and extreme exhaustion. Mostly two officer were responsible for Stanisław Michowski’s interrogation: Cpt Zdzisław Michałowski and Maj Mieczysław Notkowski. In early January 1952, Lt Roman Szulecki joined them; the last documented questioning took place on 7 August 1952 and was conducted by Lt Józef Bartczak ${ }^{57}$. Apart from never-ending interrogations, prisoners were also under surveillance by agents in their cells ${ }^{58}$. In the Institute of National Remembrance archives concerning Stanisław Michowski there are reports of an agent code-named "Orzeł". The agent observed Michowski in his cell throughout his entire arrest until late December $1951^{59}$. The documents show that he was not able to pass any significant information to their superiors. He reported that he had not noticed any sign of breakdown in the airman. He indicated that the his cell mate was quiet and that he „thinks a lot" ${ }^{\circ}$, but generally his evaluation was positive and he added that Michowski ,is disposed positively to the new reality" ${ }^{1}$. Reports in the cell agent "Orzeł" suggest that Stanisław Michowski knew exactly who his cell mate was. He was rational and calm. His laconic conversation with the call mate later became longer, but the airmen was always careful. On 4 December 1951 Michowski was confronted with Col Marian Jurecki, which was a common practice at that time. During the confrontation, Jurecki presented alleged circumstances of recruiting Michowski to "espionage organization". Michowski said where he had performed the alleged espionage. The 2nd Department of the General Staff, Headquarters of Air Forces, and the Academy of the General Staff were mentioned. However, the detainees did not provide many details of their activity. The form and the volume of the report suggests that the interrogation was only meant to confirm the guilt as understood by the $\mathrm{MDI}^{62}$. Such confrontational interrogations were a frequent practice. Interrogators hoped for inciting prisoners against each other: the prisoners, voluntarily or

${ }^{57}$ AIPN, 2386/13463, Court files Volume I, f. 3-158.

${ }^{58}$ Such agents were undercover employees of security force. Their task was to investigate the inmate, gain their trust, observe their attitude towards the investigation, extract information undisclosed during interrogations, etc. In-cell agents were usually prisoners who were no longer investigated, frequently convicted in criminal cases. Z. PALSKI, Informacja Wojska Polskiego..., p. 131-132.

${ }^{59}$ AIPN, 2386/13417, Agency's materials on Michowski Stanisław. Report of cell agent code-named “Orzel” from 3 December 1951, f. 3-15.

${ }^{60}$ Ibidem, f. 4.

${ }^{61}$ Ibidem.

${ }^{62}$ AIPN, 2386/13456, Report on confrontation of Marian Jurecki with Stanisław Michowski on 4 December 1951, f. 31-33. 
inspired by others, made testimonies harmful to others. Witnesses were also used during confrontations to suggest a specific direction of testimonies to the prisoners. This was the case with Jarecki, who was already sentenced to 15 years of imprisonment in the Tatar case when the confrontation took place. The archives of the Chief Military Prosecutor's Office from March 1955 show that his testimony, both earlier and during Michowski's confrontation, were staged ${ }^{63}$. The intention was to set the airman's testimony "to the right track" and suggest his alleged collaboration with another defendant, Col August Menczak, which was eventually achieved. What also reveals the extent to which the testimonies were fabricated is the fact that among the documents in the Institute of National Remembrance there are 23 reports of Stanisław Michowski's interrogations from 29 November 1951 to 7 August $1952^{64}$. This state of affairs is contradicted by cell receipts documenting prisoner's exits for interrogation and his returns. There are 111 of surviving receipts concerning this period ${ }^{65}$. Obviously, most of them are not in accordance with interrogation reports. This demonstrates that Michowski's testimonies which did not match investigator's expectations were not documented. It should be noted that omitting undesired testimonies was a common practice at that time. On 3 March 1952 one more confrontation was organized, this time with the already mentioned Menczak. The confrontation was short and was only meant to confirm the Michowski and Menczak's espionage collaboration suggested by Jurecki. The goal was achieved, because both detainees confirmed that they collaborated with each other, or at least this confession was reported ${ }^{66}$. Of course, the testimony was a part of fabrication prepared by the investigators. Michowski was later interrogated several times, but the reports did not survive (or were never made).

Finally, on 30 April 1952 Michowski signed the document confirming that he acquainted himself with the investigation files, that he did not contribute new testimonies and had no reservations against the previous ones ${ }^{67}$. Similarly to other defendants in this case, Michowski probably hoped that admitting to the fabricated crimes would make his sentence less severe. Equally important was the physical and mental exhaustion which must have contributed to the confirmation of the accusations. The investigation was finished on 2 May $1952^{68}$. The decision to put to criminal liability reads:

\footnotetext{
${ }^{63}$ J. PoKsIŃsKi, “TUN”,..., p. 120.

${ }^{64}$ AIPN, 2386/13463, Court files Volume I, f. 3-158.

${ }^{65}$ AIPN, 2386/13467, Michowski Stanisław, son of Józef. Volume V - personal files of prisoner, f. 22134.

${ }^{66}$ AIPN, 2386/13463, Court files Volume I. Confrontation report, 3 March 1952, f. 117-119.

${ }^{67}$ AIPN, 00161/357, Report of acquainting the suspect with investigation files, f. 231.

${ }^{68}$ Ibidem, Decision about closing investigation, f. 232.
} 
1. From July 1947 to April 1950 in Poland, Michowski Stanisław acted for the benefit of imperialistic states and undertook actions intended to overthrow the political system of the Polish state and the authorities of the Nation:

- in July 1947 he joined an organization devoted to diversion and espionage in Polish People's Army,

- as a member of this organization, he worked in a subversion and intelligence cell in the 2nd Department of the General Staff, participated in organizational meetings, recruited new members until April 1950, i.e. until he was discharged from military service.

At the same time from March 1948 he collaborated with the members of a subversion and espionage ring in the Air Force Command.

In the period described and within the above-mentioned organization, he undertook actions intended to overthrow the political system in Poland by bringing about the conditions for an Anglo-American military intervention; he intended to achieve that by treason in the army and espionage for the benefit of these countries.

2. From early 1947 to April 1950 as an officer of the Polish Army acting for the benefit of imperialistic countries, in early 1947 in England he obliged himself to a representative of the British intelligence to perform espionage activity for the foreign intelligence agency.

After returning to Poland he collected personally and through other members of the ring information about:

- Poland's defense system and national security, especially data about the reorganization of air forces and the implementation of modern air force equipment,

- official and actual personnel in air force units,

- number of air units and their location,

- units' supply in technical equipment, especially the types of aircraft and their combat value,

- combat proficiency in the entire air force and, through conducting trainings, about the methods and the scope of education of air reconnaissance officers,

- location of airfields,

- and data about the 2nd Department of the General Staff of the Polish Army, which he was delivering until December 1947 to the British attache's office in Warsaw through the defendant Jungraw and later to the command of the subversion and espionage organization; the data intended for imperialistic intelligence agencies ${ }^{69}$.

The above-mentioned decision about putting to criminal liability made by Cpt Michałowski was effectively repeated as the sentence during the trial. This state of affair testifies to the real role of the MDI in enacting "the law" in the contemporary Poland. It is worth adding that no material evidence was presented in the investigation concerning Michowski that would prove his alleged guilt. The trial of the first group of officers accused of participation in the so-called conspiratorial group in the Air Forces started on 8 May 1952 in the Supreme Military Court in Warsaw. The defendants, apart from Lt Col Stanisław Michowski, were Col Ber-

${ }^{69}$ AIPN, 2386/13463, Decision about putting to criminal liability, f. 145-146. 
nard Adamecki, Col Szczepan Ścibior, Col August Menczak, Col Józef Jungraw, Lt Col Stanisław Ziach, Lt Col Aleksander Majewski, and Lt Col Władysław Minakowski ${ }^{70}$. Judges were headed by Col Piotr Parzeniecki accompanied by Lt Col Juliusz Krupski oraz Maj Teofil Karczmarz. The prosecutor was Lt Col Jan Amons and the minutes keeper was Lt Włodzimierz Tereszczyk ${ }^{71}$. The airmen were not permitted to have a counsel for the defense, they could only try to defend themselves. All of them, hoping for a reduced sentence, sustained the testimonies made during investigations. Only Lt Col Władysław Minakowski pleaded not guilty until the very end. Michowski's death sentence, which also deprived him of public, civil, and honorary rights, and confiscated all belongings, was pronounced on 13 May 1952 $2^{72}$. Apart from Lt Col Majewski and Lt Col Ziach, who received life sentences, other officers were sentenced to death ${ }^{73}$. The sentence was validated on 10 June $1952^{74}$. The prisoners were to await execution. Stanisław Michowski had an opportunity to see his relatives for the first time since his arrest. The first visit, of his wife Irena and his son Marek, took place on $16 \mathrm{June}^{75}$; another, of his daughter Danuta, on $1 \mathrm{July}^{76}$; the last one, of his wife, on $17 \mathrm{July} 1952^{77}$. Irena Michowska wrote later: "During both visits the state of my husband was deplorable with sign of illness (absent eyes, difficulties in thinking, deafness, even though he suffered from none of these before the arrest), he claimed he was innocent"78. The convicted airman's last hope was president's pardon. Danuta, Michowski's daughter, sent a pardon request to Bolesław Bierut, and so did the convict himself. Both of the requests were declined and the sentence was to remain valid ${ }^{79}$. The minutes taken by the assistant prosecutor in the Military Prosecutor's Office Col Zbigniew Domino state that the execution by shooting was carried out on 7 August 1952 at 20.30 in Mokotów prison at 37 Rakowiecka Street in Warsaw ${ }^{80}$.

The executioner was Sgt Aleksander Drej. Apart from him, the execution was witnessed by the head of the prison Maj Alojzy Grabicki and doctor Kazimierz Jeziorski, $\mathrm{MD}^{81}$. Stanisław Michowski's belongings at the time of arrest were confiscated by

\footnotetext{
70 J. POKSIŃSKI, “TUN”,.., p. 156.

${ }^{71}$ AIPN, GK 919/1640, Sentence on the behalf of the Republic of Poland, f. 12.

72 AIPN, 1840/22, Sentence on the behalf of the Republic of Poland on 13 May 1952, f. 190-191.

73 J. PoKsiŃSKI, “TUN"..., p. 156.

${ }^{74}$ AIPN, 1840/22, Sentence on the behalf of the Republic of Poland on 13 May 1952, f. 191.

${ }^{75}$ AIPN, GK 919/1640, Permission for one-time visit, frm. 17.

${ }^{76}$ Ibidem, f. 18.

${ }^{77}$ Ibidem, f. 19.

${ }^{78}$ J. PoKsIŃSKI, Victis..., p. 55.

${ }^{79}$ Ibidem, p. 57.

${ }^{80}$ AIPN, 00161/257, Files of the case of convicted Michowski Stanisław, Report on execution, f. 11.

${ }^{81}$ Ibidem, f. 11.
} 
the state, in accordance with the sentence ${ }^{82}$. The note informing about Stanisław Michowski's execution concludes with the annotation: "Corpse to be buried"signed by Lt Col Stanisław Wackowski, the head of the 9th Department of Military Prosecutor's Office, but the site of burial is not mentioned ${ }^{83}$.

Apart from the trial convicting Stanisław Michowski, on 15 October 1952 another trial took place, in which four other airmen were accused. All of them were sentenced to death and two were executed ${ }^{84}$. In 1956 due to the Khrushchev Thaw, earlier trials were revised and many abuses and unlawful actions were revealed ${ }^{85}$. As a result of committee's investigation and revision trials, Stanisław Michowski was acquitted and rehabilitated on 9 May $1956^{86}$.

The rehabilitation of the officer could not bring him back to life. Despite official acquittal, the airmen accused of alleged conspiring in the army were committed to oblivion. Yet the memory about them is returning. As a result of research conducted by the Bureau of Search and Identification in the Institute of National Remembrance, the remains of Lt Col Stanisław Michowski were found in May 2017 in the " $E$ " quarter in Powązki Military Cemetery in Warsaw ${ }^{87}$. Another airman found in the quarter was Col Szczepan Ścibior, the head of Military Air Force School in Dęblin in 1947-1951; he was convicted as a result of the same investigation as Stanisław Michowski ${ }^{88}$.

\section{BIBLIOGRAPHY}

\section{SOURCES}

\section{Archive of the Institute of National Remembrance (AIPN)}

00161/357, Court files of the case of Lt Col Michowski Stanisław.

423/5637, Case concerning Stanisław Michowski.

${ }^{82}$ AIPN, 00161/257, Files of the case of convicted Michowski Stanisław, Report from 20 November 1952 from the Liquidation Department in Warsaw concerning the possessions of Stanisław Michowski, f. 17.

${ }^{83}$ Ibidem, Files of the case of convicted Michowski Stanisław, Report from 7 August 1952 informing about Stanisław Michowski's execution, f. 12.

${ }^{84}$ J. PoKsińsKi, “TUN"..., p. 154.

85 “My, sędziowie nie od Boga...”. Z dziejów sądownictwa wojskowego PRL 1944-1956. Materiały i dokumenty, red. J. Poksiński, Warszawa 1990, p. 239-241.

${ }^{86}$ J. PoksińsKi, Victis..., p. 57.

${ }^{87}$ Stanisław Michowski, "Instytut Pamięci Narodowej. Biuro Poszukiwań i Identyfikacji” [online, accessed: 16 II 2019], available at: <https://poszukiwania.ipn.gov.pl/bbp/odnalezieni/1732,Stanislaw-Michowski.html>.

${ }^{88}$ Szczepan Ścibior, "Instytut Pamięci Narodowej. Biuro Poszukiwań i Identyfikacji” [online, accessed: 16 II 2019], available at: <https://poszukiwania.ipn.gov.pl/bbp/odnalezieni/7363,Szczepan-Scibior.html>. 
1840/22, Soldier's personal file: Lt Col Michowski Stanisław.

2386/13417, Agency's materials on Michowski Stanisław.

2386/13418, Court files of the case of Adamecki and others.

2386/13463, Court files Volume I.

2386/13466, Court files Volume IV. Memorandum and additional materials.

2386/13467, Michowski Stanisław, son of Józef. Volume V - personal files of prisoner.

GK 919/1640, Personal files of prisoner: Michowski Stanisław.

\section{Central Military Archive (CAW):}

II.53.35965, Register of soldiers returning to Poland for permanent residence from foreign military units. Collection of files of Polish soldiers returning from the Polish Armed Forces in the West 1945-1948.

\section{Digital Library of Wielkopolska}

Personal journal 1928.03.21 R.9 no. 8 .

\section{PRINTED SOURCES}

“My, sędziowie nie od Boga... ”. Z dziejów sądownictwa wojskowego PRL 1944-1956. Materiały i dokumenty, red. J. Poksiński, Warszawa 1990.

\section{MEMORIES}

Marek Michowski. Syn bohatera Dywizjonu 305 [memories of Marek Michowski, son of Stanisław Michowski], "Polskie Radio" [online], 21 X 2016 [accessed: 26 I 2019], available at: <https:// www.polskieradio.pl/8/755/Artykul/1681062,Marek-Michowski-Syn-bohatera-Dywizjonu-305>.

\section{MONOGRAPHS}

Belcarz B., Polacy w Clermont-Ferrand, "Lotniczy Magazyn Historyczny 'Gapa”, 14(2015).

EISLER J., Siedmiu wspaniałych. Poczet pierwszych sekretarzy KC PZPR, Warszawa 2014.

Matusiak W., Powojenne losy elity polskiego lotnictwa, „Biuletyn Instytutu Pamięci Narodowej”, $3(2011)$.

PALSKI Z., Informacja Wojska Polskiego 1943-1957, Warszawa 2016.

Pawlak J., Polskie eskadry w latach 1918-1939, Warszawa 1989.

Poksiński J., “TUN”. Tatar - Utnik - Nowicki. Represje wobec oficerów wojska polskiego w latach 1949-1956, Warszawa 1992.

PoKsIŃski J., Victis Honos, Warszawa 1994.

Radomski J.A., Demobilizacja Polskich Sił Zbrojnych na Zachodzie w latach 1945-1951, Kraków 2009.

Tochman K.A., Z ziemi obcej do Polski. Losy żolnierzy PSZ na Zachodzie, którzy powrócili do kraju po II wojnie światowej, t. 1, Zwierzyniec 2006. 


\title{
INTERNET SOURCES
}

Harbin, "Britannica" [online, accessed: 20 II 2019], available at: <https://www.britannica.com/place/ Harbin>.

Harbin, "Encyklopedia PWN" [online, accessed: 20 II 2019], available at: $<$ https://encyklopedia.pwn. $\mathrm{pl} /$ haslo/Harbin;3910038.html>.

Stanisław Michowski, "Instytut Pamięci Narodowej. Biuro Poszukiwań i Identyfikacji” [online, accessed: 16 II 2019], available at: <https://poszukiwania.ipn.gov.pl/bbp/odnalezieni/1732,Stanislaw-Michowski.html>.

Szczepan Ścibior, "Instytut Pamięci Narodowej. Biuro Poszukiwań i Identyfikacji” [online, accessed: 16 II 2019], available at: <https://poszukiwania.ipn.gov.pl/bbp/odnalezieni/7363,Szczepan-Scibior. html>.

Zarzadzenia Prezydenta Rzeczypospolitej ['Ordinance of the President of the Republic of Poland'], "Dziennik Personalny" ['Personal Journal'], 21 III 1928, f. 2, available at: $<$ http://www.wbc.poznan.pl/dlibra/applet?mimetype=image $\% 2 \mathrm{Fx} . d j v u \& s e c=$ false\&handler=djvu_html5\&content_url=\%2FContent $\% 2 F 69628 \% 2 F d i r e c t o r y . d j v u>$ [accessed: 16 II 2019].

\section{PPŁK DYPL. OBS. STANISŁAW MICHOWSKI \\ A SPISEK W WOJSKU ZBRODNIA USANKCJONOWANA}

\begin{abstract}
Streszczenie. Artykuł prezentuje postać ppłk. dypl. obs. Stanisława Michowskiego w kontekście represji politycznych w Polsce przełomu lat czterdziestych i pięćdziesiątych XX w. Bohater tekstu to lotnik Polskich Sił Powietrznych, który po drugiej wojnie światowej powrócił do kraju i na nowo rozpoczął służbę w wojsku, lecz po krótkim czasie został z niego usunięty i niedługo potem aresztowany. Został jednym z oskarżonych, a następnie skazanych i straconych w konsekwencji wydarzeń znanych w historiografii jako spisek w wojsku. Operacja przeprowadzona przez organy Głównego Zarządu Informacji Wojska Polskiego wymierzona była przede wszystkim w żołnierzy przedwrześniowych, żołnierzy służących w Polskich Siłach Zbrojnych na Zachodzie oraz tych, którzy w czasie wojny przebywali na terenie kraju i działali w organizacjach konspiracyjnych. Jako lotnik Michowski został oskarżony o udział w konspiracyjnej grupie Wojsk Lotniczych, której zadaniem miało być spiskowanie przeciwko władzy komunistycznej i dążenie do obalenia jej siłą, za pomocą struktur wojskowych. Zarzuty stawiane wówczas oskarżonym w przytłaczającej większości nie miały nic wspólnego z rzeczywistością. Akty oskarżenia, na podstawie których w wielu przypadkach sądy orzekały karę śmierci, opierały się na zeznaniach preparowanych podczas wielogodzinnych przesłuchań.
\end{abstract}

Słowa kluczowe: proces odpryskowy, Stanisław Michowski, spisek w wojsku, represje polityczne w Polsce po 1945 r. 